\title{
Strategic Planning Process Towards Sustainability: Collective Case Study Approach
}

\author{
Periyasami Anbarasan ${ }^{1}$ \\ ${ }^{1}$ Department of Management Studies, Indian Institute of Technology Delhi (IIT-D) Vishvakarma Bhavan, New Delhi, \\ India \\ Correspondence: Periyasami Anbarasan, Department of Management Studies, Indian Institute of Technology Delhi \\ (IIT-D) Vishvakarma Bhavan, New Delhi, 110016, India. E-mail: jeevakarunyam@gmail.com
}

Received: November 19, 2019

Accepted: March 2, $2020 \quad$ Available online: March 6, 2020

doi:10.11114/ijsss.v8i3.4754

URL: https://doi.org/10.11114/ijsss.v8i3.4754

\begin{abstract}
The study developed a meta-framework for the strategic planning process, which is an inter-dynamic aspect of strategic processing. Furthermore, it follows multiple case study analysis, and panel data regression analysis conducted to validate the study, the limitations and future scope of the research discussed along with the result. The asset of an organization considered as an essential element in sustainable business practices, hence the three predictors taken from asset section of financial statements of case organizations and the results discussed such as cash and cash equivalent is an important factor for practicing sustainability.
\end{abstract}

Keywords: strategic planning process, sustainability, meta-framework, case study, panel data

\section{Introduction}

In endurance to an organization or an institution; strategic planning is a significant action that determines the organization's future goals and performances. Complexity persists not only with the organizational structure but also in terms of defining descriptions and explanations that are complex concepts. Hence strategic planning is viewed from a corporate perspective and the process involved with it. Strategic planning clarifies certain vital situations that are yet be answered or need to focus on a particular case, element or factor. Strategic planning process enhances the opportunity to maximize business performances and provides possible alternatives as decisions or route map. Thus it an independent action that offers an eagle view towards organizational progress and its heading directions that are more likely towards the chances of success. Successful strategic planning is crucial in the strategic planning process. Because every board capital aspires to the achievements and strategic design plan for smooth and successful organizational operations. Hence it is an imperative factor in achieving sustainability through the successful strategic planning process.

\section{Methodology}

The study reviews the literature on a strategic planning process to perceive the knowledge obtained, and there are two methodologies applied in this study; i) Multiple case study methods and ii) Panel data analysis regression and finally the goodness of fit test is conducted for the obtained two models. For the multiple case study, three firms had been taken, such as Brambles, OZ Minerals and Aramex. The firm's strategic directions and values are studied to follow its sustainability commitments. And from the three firms, the data are collected for validation the study purposes.

\subsection{Data}

The data are secondary data collected from the balance sheet of the respective firm's consolidated financial statements. The data collected from 2008 to 2017, and there is a thirty observation point. From the current asset cash and cash equivalent is taken that is proxy with immediate hand cash. Employee benefit expenses and goodwill -intangibles are taken non-current asset. Model one is OLS regression analysis, and Model two is Random effect model shown in Table 2 and 3.

\section{Views on Strategic Planning: A Literature Review}

Strategic planning requires priorities, that explains, the main focus of organization desirable strategic outcome. According to Mason (1969) Planning process that requires a unique style, and that exceedingly difficult in framing towards the expert approach. Hence strategic planning requires specific essential priorities. For instance, strategic 
planning for channel enhancement, strategic planning for community development requires particular knowledge and involved factors are crucial. The priorities are narrowed one from the broader perspectives. In general, the strategic plan has the number of advantages such as gives an insight towards the strategic environment, the stumbling blocks and the understanding of organization performances (O'Regan and Ghobadian, 2002).

Some scholars explain that the lack of accountability in strategic planning is one crucial reason for weaker planning performances (King, 1983). The need for a new dimension in values, approach and process in strategic planning through the learning process was put forth by Albrechts (2004). Likewise, Heracleous (1998) says that strategic planning needs an analytical thought process and a different thought process. For the success in strategic planning, Bryson et al. (2018) state that different kinds of leadership, particularly board participation, will enhance the chances of diplomatic planning successes. In the study conducted by Noto and Noto (2019) where strategic planning is applied to identify the performance of local system linking through a stakeholder approach. Hence regulating the planning process through answering the existing vacuum will lead to the long- term sustainable planning practices (Hytönen and Ahlqvist, 2019) and thus firms do recognize the usefulness of strategic planning (Boyd, 1991).

\subsection{The Importance of Strategic Planning in an Organization}

Planning yield too much rigidity and organizations are obliged to deal with uncertainty. Hence a systematic approach in planning continues to remain as a problem (Miller \& Cardinal, 1994) Many issues that seem to be important not examined including the roles of mission, conflicting goals, external players and activities pursued (Crittenden \& Crittenden, 1997). Strategic planning requires, intervention and implementation are possible only when the management process and the analytical process are understood from the organizational perspectives (Tomlinson \& Dyson 1983) however, Strategic planning provides better performance through analyzing the attribute that is related to the characterization of effectiveness (Dyson \& Foster,1983).

According to Ketokivi \& Castaner (2004), strategic planning consists of a set of goals, that is further communicated adequately to the organizational units, ensuring that corporate members understood their organization planning approach. Strategic planning requires communication that insists on the importance of a structured plan in strategic planning.

\subsection{Strategic Planning Leads to Sustainability Governance}

According to Abbott (2012) "Many scholars view business as driving factor in Private sustainability governance, Business can dominate because of its 'go-it-alone power': business expertise, resources and managerial authority allow firms and industry associations to adopt and implement business-friendly standards." Similarly, the case study on ISEAL developed by Loconto and Fouilleux (2013) shows that the firm opted for internal and external legitimating strategies to institutionalize sustainability. However, Luks and Siebenhüner (2007) say that multiple complexities and multiple actors that related to sustainability require a different approach. Rasche and Waddock (2014) explained the importance of participation, transparency and quality in sustainability governance. Authors are grave concerns about intuitionalism sustainability and different approach that enhances the understanding of their practices; instead of viewing sustainability through enforcing mechanism.

\section{Strategic Planning Process: An Overview}

The strategic planning process is concerned about three essential aspects such as the essentials of mechanism, that explains as to how the planning process involved will tackle the raised issue? What are the objectives that are in immediate concern? Such questions related to process developing mechanism. Then comes the means, to conduct the planning process and finally, the course of action. That shown in Figure 1. 


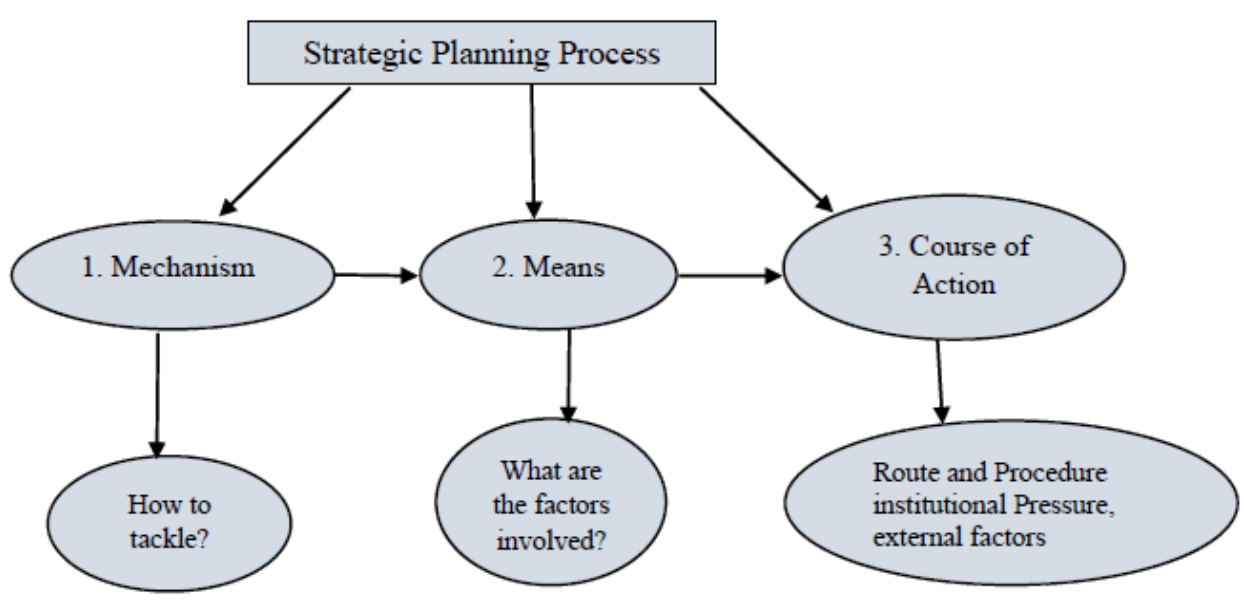

Figure 1. Shows criteria involved in strategic planning process

\subsection{Mechanisms for the Strategic Planning Process}

In this channel, the strategic planning process is involved with steps or envoy that can facilitate the strategy. In terms of sustainable business practices, the organization is committed to producing the agro-products or eco-friendly products, or creating awareness towards green products by generating supply oriented demand; that means the enterprise is aspiring towards providing environmentally friendly products to gain a sustained competitive advantage in an existing market or channel enhancement. Therefore, the organization will involve in identifying product details, the customer base (the target population), the mode of reaching and so on, such tools or types of equipment considered as a mechanism in the strategic planning process.

\subsection{Means}

Means are the mode of achieving the expected result that requires the governance criteria or similar factor. Such as; the sustainability practised through different channels as utilizing the certified raw materials, encouraging organic farming, initiating green supply chain management in receiving raw materials and actively engaging employees are some of the identified means in sustainable business practices. While framing the desired goal, Such identified means have to explicitly explain the significant contributing element in achieving the desired goal.

\subsection{Course of Actions}

Sustainable business practices can be actualizing through increasing intermediate asset, such as developing the corporations own, poultry farms, dairy farms, creating social forestry for immediate raw materials needs and the action ground have to be within the access point of board capital or working groups. Under this criterion, the strategic planning process developed. The case study applied meta-framework is shown in Figure 2. 


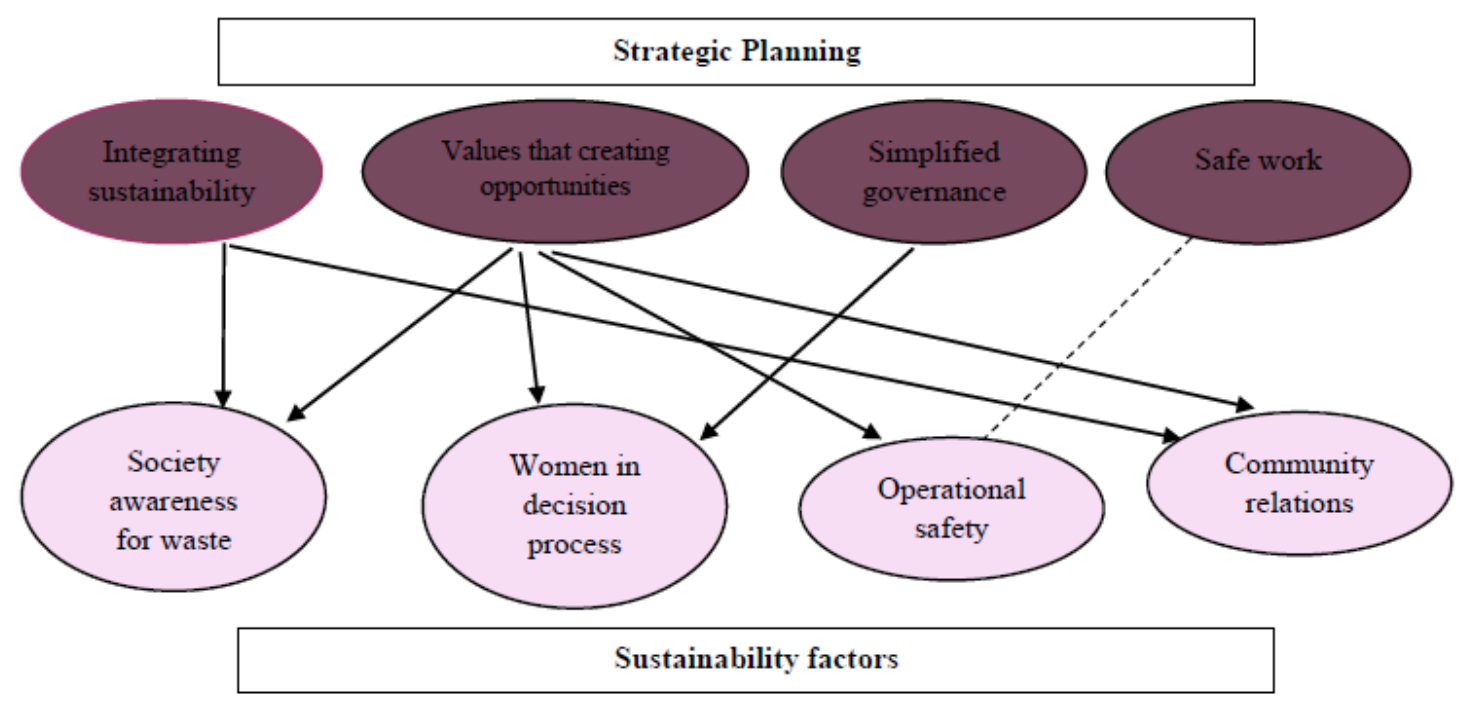

Figure 2. the strategic planning from case organizations perspective

\section{Multiple Case Study Analysis}

There are three case studies taken, such as Aramex, OZ Minerals and Brambles. These three case studies had carried to understand their value focus to find their sustainability commitments and their strategic directions towards sustainability. Aramex is a global leader in logistics and transportation, Brambles that are related pallets and containers known for its proper practice on circular economy and reuse policy. Similarly, OZ minerals, a mining company, is focused on employee workplace safety, and creating values across diverse operations. The case organizations sustainability practices and strategic views are shown in Table 1 and Table 2.

Table 1. Shows the social performance of case organizations

\begin{tabular}{|l|l|}
\hline Social Performances & Case Organizations \\
\hline Social impact of value chain & Brambles \\
\hline Society awareness of waste & Brambles \\
\hline Providing management roles to women & Brambles \\
\hline Sustaining communities & Aramex \\
\hline Resource efficiency & Aramex \\
\hline Operational safety & OZ minerals \\
\hline Maintaining community relations & OZ minerals \\
\hline
\end{tabular}

Table 2. Shows the case organizations strategic plan towards sustainability

\begin{tabular}{|l|l|}
\hline Strategic plans & Case organizations \\
\hline Integrating sustainability into operations & Aramex \\
\hline Growth and value that create opportunities & Brambles \\
\hline Network advantage & Brambles \\
\hline Simplified governance process & OZ Minerals \\
\hline Reliable mining culture and safe work & OZ Minerals \\
\hline
\end{tabular}

All these three corporations are focused on creating value through their services. Bramble is focusing on developing a sustainability risk committee as a part of their action plan. Similarly, OZ minerals have sustainability governance framework, and Aramex has incorporated sustainability as a strategy. Hence these three case studies a taken for practical study purpose. The data collected are shown in Table 3. 
Table 3. Predictors for the study In Million Dollars

\begin{tabular}{|c|c|c|c|c|}
\hline Cash and Equivlaent & Employee benefits and Pensions & Goodwill and intangibles & Firm ID & Year \\
\hline 159.7 & 51.6 & 1028.1 & 1 & 2017 \\
\hline 156.1 & 47.5 & 1635.2 & 1 & 2016 \\
\hline 166.2 & 55 & 1751 & 1 & 2015 \\
\hline 222.3 & 60.9 & 1543.5 & 1 & 2014 \\
\hline 128.9 & 51.2 & 2073.2 & 1 & 2013 \\
\hline 174.2 & 58.8 & 1969.6 & 1 & 2012 \\
\hline 138.5 & 37.4 & 2098 & 1 & 2011 \\
\hline 135.5 & 50.4 & 765.6 & 1 & 2010 \\
\hline 90.1 & 50.8 & 775.3 & 1 & 2009 \\
\hline 104.8 & 63.4 & 863 & 1 & 2008 \\
\hline 729.4 & 56.2 & 0 & 2 & 2017 \\
\hline 655.7 & 60.4 & 284.9 & 2 & 2016 \\
\hline 552.5 & 63.9 & 252.2 & 2 & 2015 \\
\hline 218.5 & 69.2 & 252.2 & 2 & 2014 \\
\hline 364 & 78.5 & 252.2 & 2 & 2013 \\
\hline 659 & 79.2 & 252.2 & 2 & 2012 \\
\hline 886.1 & 66.6 & 253.1 & 2 & 2011 \\
\hline 1334.2 & 52.5 & 0 & 2 & 2010 \\
\hline 1076.2 & 60.8 & 0 & 2 & 2009 \\
\hline 48.01 & 139.09 & 3.16 & 2 & 2008 \\
\hline 198.1 & 38.27 & 378.52 & 3 & 2017 \\
\hline 190.93 & 37.79 & 356.8 & 3 & 2016 \\
\hline 192.52 & 35.27 & 296.06 & 3 & 2015 \\
\hline 168.79 & 32.05 & 305.05 & 3 & 2014 \\
\hline 178.86 & 28.06 & 271.58 & 3 & 2013 \\
\hline 90.84 & 24.82 & 279.34 & 3 & 2012 \\
\hline 85.49 & 21.69 & 283.27 & 3 & 2011 \\
\hline 151.03 & 18.23 & 237.44 & 3 & 2010 \\
\hline 136.63 & 16.23 & 233.9 & 3 & 2009 \\
\hline 93.61 & 14.16 & 220.04 & 3 & 2008 \\
\hline
\end{tabular}

Source: Annual report of firms (01-Brambles; 02-OZ minerals; 03- Aramex)

From the obtained predictors, such as cash and cash equivalents, employee benefits and Pensions and thirdly goodwill and tangibles are taken for validation of the study. These three companies are incorporated sustainability through governance, strategic directions and in the planning process. Hence the asset of an organization is related to their economic value. Already they have sustainability commitments. Thus financial cost will further enhance their sustainability commitments in the long run. Therefore, cash and cash equivalent took from the current asset - likewise, employee benefit expenses and goodwill and intangibles taken from the non-current asset. The data collected from the financial statements of the respective firms. Panel data regression analysis conducted with thirty observation point over the year 2008 to 2017.

\subsection{Result}

Two models have been developed such as OLS regression and random effect model to understand further the goodness of fit model, LM test (Breush and Pagan test) conducted shown in Table 6 that shows that pooled OLS regression is appropriate for the study. Both the regression models are shown in Table 4 and 5. 
Table 4. Pooled OLS Regression Model (Model 1)

\begin{tabular}{|c|c|c|c|c|c|c|}
\hline Cash and Cash Equivalent & Coef. & Std. Err. & $\mathrm{t}$ & $P>|t|$ & {$[95 \%$ conf } & aterval] \\
\hline $\begin{array}{l}\text { Employee benefits and Pension } \\
\text { obligations }\end{array}$ & 2.874065 & 2.290355 & 1.25 & 0.220 & -1.825356 & 7.573486 \\
\hline Goodwill and Intangibles assets & -.1856034 & .0838719 & -2.21 & 0.036 & -.3576942 & -.0135126 \\
\hline _cons & 287.6278 & 140.4487 & 2.05 & 0.050 & -.5490708 & -.0135126 \\
\hline Number of Observations & \multicolumn{6}{|l|}{30} \\
\hline R square & \multicolumn{6}{|l|}{0.1981} \\
\hline Adjusted R square & \multicolumn{6}{|l|}{0.1387} \\
\hline F value $(2,27)$ & \multicolumn{6}{|l|}{3.33} \\
\hline Prob $>F$ & \multicolumn{6}{|l|}{0.0508} \\
\hline
\end{tabular}

Table 5. GLS Random Effect Model (Model 2)

\begin{tabular}{|c|c|c|c|c|c|c|}
\hline Cash and Cash Equivalent & Coef. & Std. Err. & $\mathrm{Z}$ & $\mathrm{P}>|\mathrm{Z}|$ & [95\% conf. & nterval] \\
\hline $\begin{array}{l}\text { Employee benefits and Pension } \\
\text { obligations }\end{array}$ & 2.874065 & 2.290355 & 1.25 & 0.210 & -1.614949 & 7.363079 \\
\hline Goodwill and Intangibles assets & -.1856034 & .0838719 & -2.21 & 0.027 & -.3499892 & -.0212176 \\
\hline _cons & 287.6278 & 140.4487 & 2.05 & 0.041 & 12.35346 & 562.9022 \\
\hline Number of Observations & \multicolumn{6}{|l|}{30} \\
\hline R square & 0.1043 & 0.7767 & \multicolumn{4}{|l|}{0.1981} \\
\hline Wald chi2 (2) & \multicolumn{6}{|l|}{6.67} \\
\hline Prob> chi 2 & \multicolumn{6}{|l|}{0.0356} \\
\hline Sigma_u & \multicolumn{6}{|l|}{0} \\
\hline Sigma_e & \multicolumn{6}{|l|}{188.5161} \\
\hline rho & \multicolumn{6}{|l|}{0} \\
\hline
\end{tabular}

Table 6. Goodness of Fit test (LM TEST)

\begin{tabular}{|c|lcc|}
\hline & Var & sd = sqrt $($ Var $)$ \\
\hline Cashand t & 106108.7 & & 325.7434 \\
\hline $\mathrm{e}$ & 35538.32 & & 188.5161 \\
\hline $\mathrm{u}$ & & 0 & 0 \\
\hline
\end{tabular}

Test: $\operatorname{Var}(\mathrm{u})=0$

$$
\begin{aligned}
& \text { chibar2 }(01)=0.00 \\
& \text { Prob }>\text { chibar } 2=1.0000
\end{aligned}
$$

OLS regression analysis shows that spending on goodwill and intangibles are inversely explaining the cash and cash equivalents. Spending more on goodwill and intangibles will inversely affect the easy money or payment in hand, particularly in the competitive environment, where the asset is needed to be protected and enhanced for long run business activities. The cash and cash equivalents are essential for conducting successful business activities that even has a significant phenomenal contribution to the organization value system.

\section{Conclusion}

The strategic planning process is an inter- dynamic aspect of strategic thinking. When the active elements of strategies are evident in approach, then the inter dynamics will be facile. The meta-framework for strategic planning process developed to show how it is varying from the existing method, and it exhibits the skeleton form of the process involved. Further, the empirical analysis validated the study through panel data analysis that is significantly explaining the importance of cash and cash equivalents through its inverse relationship with goodwill and intangibles. The brands are created not by spending but rather by the efforts and constant labour of the founding fathers of the respective organizations. The name or image developed through their business skills and unique business tactics involved, hence mere spending on brand value and customer base value may not serve the purpose of sustained business activities or with the aim of channel 
enhancement or searching new markets. It requires proper strategic planning and strategic directions for sustainable business practices.

\section{Limitation of the Study}

The study is limited to the strategic planning meta-framework analysis.

\section{The Future Direction of the Study}

The need for developing a tactical framework and identifying the potential factors that are contributing towards strategic planning process is the future scope of the study.

\section{References}

Abbott, K. W. (2012). Engaging the public and the private in global sustainability governance. International Affairs, 88(3), 543-564. https://doi.org/10.1111/j.1468-2346.2012.01088.x

Boyd, B. K. (1991). Strategic planning and financial performance: a meta-analytic review. Journal of Management Studies, 28(4), 353-374. https://doi.org/10.1111/j.1467-6486.1991.tb00286.x

Bryson, J. M., Edwards, L. H., \& Van Slyke, D. M. (2018). Getting strategic about strategic planning research. Public Management Review, 20(3), 317-339. https://doi.org/10.1080/14719037.2017.1285111

Crittenden, W. F., \& Crittenden, V. L. (1997). Strategic planning in third-sector organizations. Journal of Managerial Issues, 86-103.

Dyson, R. G., \& Foster, M. J. (1983). Effectiveness in strategic planning revisited. European journal of operational research, 12(2), 146-158. https://doi.org/10.1016/0377-2217(83)90218-7

Hytönen, J., \& Ahlqvist, T. (2019). Emerging vacuums of strategic planning: an exploration of reforms in Finnish spatial planning. European Planning Studies, 1-19. https://doi.org/10.1080/09654313.2019.1580248

Ketokivi, M., \& Castaner, X. (2004). Strategic planning as an integrative device. Administrative Science Quarterly, 49(3), 337-365. https://doi.org/10.2307/4131439

King, W. R. (1983). Evaluating strategic planning systems. Strategic Management Journal, 4(3), 263-277. https://doi.org/10.1002/smj.4250040307

Loconto, A., \& Fouilleux, E. (2014). Politics of private regulation: ISEAL and the shaping of transnational sustainability governance. Regulation \& Governance, 8(2), 166-185. https://doi.org/10.1111/rego.12028

Luks, F., \& Siebenhüner, B. (2007). Transdisciplinarity for social learning? The contribution of the German socio-ecological research initiative to sustainability governance. Ecological Economics, 63(2-3), 418-426. https://doi.org/10.1016/j.ecolecon.2006.11.007

Miller, C. C., \& Cardinal, L. B. (1994). Strategic planning and firm performance: A synthesis of more than two decades of research. Academy of management journal, 37(6), 1649-1665. https://doi.org/10.5465/256804

Noto, G., \& Noto, L. (2019). Local Strategic Planning and Stakeholder Analysis: Suggesting a Dynamic Performance Management Approach. Public Organization Review, 19(3), 293-310. https://doi.org/10.1007/s11115-018-0403-0

O'Regan, N., \& Ghobadian, A. (2002). Formal strategic planning: the key to effective business process management?. Business Process Management Journal, 8(5), 416-429. https://doi.org/10.1108/14637150210449102

Tomlinson, R., \& Dyson, R. (1983). Some systems aspects of strategic planning. Journal of the Operational Research Society, 34(8), 765-778. https://doi.org/10.1057/jors.1983.170

\section{Copyrights}

Copyright for this article is retained by the author(s), with first publication rights granted to the journal.

This is an open-access article distributed under the terms and conditions of the Creative Commons Attribution license which permits unrestricted use, distribution, and reproduction in any medium, provided the original work is properly cited. 